3P181

\title{
アクチン細胞骨格と核とのカ学的結合が血管平滑筋細胞の分 化に与える影響
}

Effects of Actin-Nucleus Connections on the Vascular Smooth Muscle Cell Differentiation

Kazuaki Nagayama ${ }^{1}$, Makoto Iwata ${ }^{2}$, Takeo Matsumoto ${ }^{2}\left({ }^{1}\right.$ Department of Intelligent Systems Engineering, Ibaraki University, Japan, ${ }^{2}$ Department of Mechanical Engineering, Nagoya Institute of Technology, Japan)

Vascular smooth muscle cells (VSMCs) dedifferentiate from contractile to synthetic phenotype under pathological conditions. To understand smooth muscle pathophysiology, it is important to understand the mechanism of their differentiation and dedifferentiation. We recently found that the actin stress fibers (SFs) have a mechanical interaction with the nucleus, and the internal forces of SFs were transmitted directly to the nucleus. Thus, it is possible that the mechanical interaction between SFs and nuclei could be associated with gene transcription and cell differentiation. Here we investigated the alterations in the mechanical interaction between actin cytoskeleton and the nucleus during the differentiation and dedifferentiation processes of VSMCs.

3P18

\section{繰り返し伸展刺激によって起こるストレスファイバーの脱重 合のメカニズムについて}

What is the molecular mechanism of stress fiber disassembly caused by mechanical cyclic stretch?

Wenjing Huang ${ }^{2}$, Tsubasa Matsui ${ }^{1}$, Masahiro Kuragano ${ }^{3}$, Masayuki Takahashi ${ }^{3}$, Tomohiro Kawahara ${ }^{2}$, Masaaki Sato ${ }^{4}$, Shinji Deguchi ${ }^{1}$ ( ${ }^{1}$ Nitech, ${ }^{2}$ Kyutech, ${ }^{3}$ Hokkaido Univ, ${ }^{4}$ Tohoku Univ)

The mechanism underlying selective disassembly of stress fibers (SFs) oriented in the direction of cyclic stretch remains unclear. Here, we show that fast shortening of cells that exceeds the intrinsic contraction speed of SFs causes disassembly of SFs. SFs that contained myosin light chain mutants whose actin-myosin-II interactions were restricted were more prone to disassembly upon fast cell shortening. We overexpressed active LIM-kinase mutants to inactivate cofilin, and found that disassembly of SFs still occurred in a manner similar to that of controls. We suggest that the disassembly is caused by the unbundling of constituent actin filaments in a manner critically dependent on myosin II but independent of the severing activity of cofilin.

3次元コラーゲンゲル内に培養された線維芽細胞のメディウ ムの流れ刺激に対する反応

Responses of fibroblasts against fluid flow stimuli in a threedimensional collagen gel culture system

Natsumi Saito ${ }^{1}$, Hiroaki Adachi ${ }^{2}$, Hiroshi Tanaka ${ }^{2}$, Satoru Nakata ${ }^{2}$, Norifum Kawada $^{1}$, Katsutoshi Yoshizato ${ }^{1}$ ( ${ }^{1}$ Dept. Hepatology, Grad. Sch. Med., Osaka City Univ., ${ }^{2}$ Nippon Menard Cosmetic Co., Ltd.)

Cells in vivo are bathed in the interstitial fluid and it has been said that the fluid flow-derived stimulus is one of the basic constraints that determine cells' basic phenotypes in vivo. Cells in the three-dimensional (3D) collagen gel culture are known to recapitulate their in vivo phenotypes. The effects of medium flow-stimulus on human fibroblasts were studies using this culture method. The cells were supplied with medium through a pumpdriven syringe at a regulated velocity $(0.012 \mu \mathrm{m} / \mathrm{s}$ to $1.5 \mu \mathrm{m} / \mathrm{s})$ and characterized for their various phenotypes. The medium flow-stimulus activated the cell growth in a velocity-dependent manner, the expression of hyaluronan synthetase 2 gene, and markedly increased the gel's wet volume.

\section{P184}

細胞シート延伸における細胞核変形量の測定

Measurements of cell nucleus deformation during stretching a cell sheet

Kota Onishi, Masahiro Tsuchiya, Takaharu Okajima (Grad. Sch. Inform. Sci. and Techno. Hokkaido Univ.)

Cells have an ability to activate their cell functions in response to external forces. Mechanical properties of cells have been widely studied in single cells, but less in cell population. Here, we investigated how cell nucleus deforms in response to uniaxial external forces, using cell sheet of COSFucci (RIKEN) [1] by monitoring the fluorescence of nucleus depending on cell phase. We found that the deformation of nucleus was proportional to that of the whole cell sheet, but the former value was much less than the latter indicating a heterogeneous deformation of intracellular structures. Detailed results for the cell cycle dependence will be presented. We thank Dr. Atsushi Miyawaki for COS-Fucci and NMuMG-Fucci cells. [1]A. Sakaue-Sawano.et.al.,Cell 132, 487 (2008)

Microfluidics analyses of coordinated dynamics of F-actin and cAMP signaling in Dictyostelium chemotaxis

Fumihito Fukujin ${ }^{1,2}$, Satoshi Sawai ${ }^{1,3,4}\left({ }^{1}\right.$ Graduate School of Arts and Science, University of Tokyo, ${ }^{2}$ Research Fellow of Japan Society for the Promotion of Science, ${ }^{3}$ Research Center for Complex Systems Biology, University of Tokyo, ${ }^{4}$ PRESTO, Japan Science and Technology Agency)

In migrating Dictyostelium, chemoattractant field is dynamic, selfgenerated and amplified by the moving cells themselves. How the cell movement and the amplification of guidance cue are coordinated in space and time remains elusive. Here we study the role of actin polymerization on the chemoattractant cAMP-induced elevation of cAMP. We show by combining FRET-based live-cell imaging of cytosolic cAMP and microfluidics that the amplitude and the timescale of the response are altered when actin polymerization is pharmacologically inhibited. The population-level oscillations of cAMP also diminished under latrunculin treatment, suggesting that self-generation of chemoattractant cAMP field is linked strictly to cell movement.

\section{$3 \mathrm{P} 186$}

\section{紡鍾体の力学特性の遷移は染色体分配を手助けする}

Mechanical transition of the vertebrate meiotic spindle facilitates chromosome dynamics

Jun Takagi ${ }^{1}$, Takeshi Itabashi ${ }^{2}$, Shin'ichi Ishiwata ${ }^{2,3}$ ( ${ }^{1}$ Quantitative Mechanobiology Laboratory, NIG, ${ }^{2}$ Fac. Sci. Engn., Waseda Univ., ${ }^{3}$ WABIOS, Waseda Univ.)

Activities of molecules such as molecular motors and microtubules are well regulated depending on cell cycle phases to organize a mitotic/meiotic spindle. Currently, we do not know whether the mechanical properties of the spindle differ in stages of mitotic/meiotic phase, and whether this difference contributes to mitotic stage-dependent mechanical works such as congression and segregation of chromosomes. Here, we measured the mechanical properties of the metaphase and anaphase spindles assembled in Xenopus egg extracts using a pair of force-calibrated micro-needles. We found that anaphase spindles are less elastic than metaphase spindles against the stretching force, of which direction is the same as that of spindle elongation at anaphase. 